\title{
TRENDS IN ROMANIAN AGRITOURISM IN THE CONTEXT OF SUSTAINABLE TOURISM DEVELOPMENT
}

\author{
Diana Foris, Assistant Professor'; Ioana Sonia Comanescu, Associate Professor ${ }^{2}$; \\ Tiberiu Foris, Professor ${ }^{3}$
}

1, 2 Faculty of Food and Tourism, Transilvania University of Brasov

${ }^{3}$ Faculty of Economic Sciences and Business Administration, Transilvania University of Brasov

\begin{abstract}
Agritourism plays an important role for sustainable development, acting as integrator for other economic sectors, like agriculture, transport, services, preserving the traditions and historical heritage. This study presents the analysis of the evolution of the agritourism infrastructure and of the main tourism indicators for Romania as agritourism travel destination, emphasizing the importance of this sector in the development of the tourism industry. Quantitative and comparative analyses were carried out regarding the total number and the existing accommodation capacity for tourist boarding houses and agritourist boarding houses and the numerical evolution for domestic arrivals and international arrivals throughout the period between 2006 and 2016. In conclusion, Romania is an important agritourism destination, well known at national and international level for its natural and anthropic resources in rural areas.
\end{abstract}

Keywords: agritourism, agritourism infrastructure and accommodation capacity, tourist arrivals, sustainable development

JEL codes: O18, Q56, Z31, Z32

\section{INTRODUCTION}

In European Union, rural tourism is a concept that includes tourist activity organized and led by the local population, based on a close connection with the natural and human environment (Caratus Stanciu, 2017). Agritourism is directly linked to agricultural activities, being practiced by small farmers and these activities carried out in their own household are the main source of income.
At this moment, both in our country and in the European Union, rural tourism and ecotourism are among the most dynamic forms of tourism, a result of the advantages which it offers to both tourists and host communities. Rural areas are rich in ecological and rural diversity (Dorobantu and Nistoreanu, 2012) to which adds up the tourism resources (natural, cultural and human) and the tourism facilities and equipment, including tourist boarding houses and agritouristic farms as well (Nistoreanu, 2007).

\footnotetext{
${ }^{1}$ Corresponding author: B-dul Eroilor 29, Brasov, Romania, diana.foris@unitbv.ro, +40 723567846

${ }^{2}$ Corresponding author: B-dul Eroilor 29, Brasov, Romania, ioanacom@unitbv.ro, +40 722789069

${ }^{3}$ Corresponding author: B-dul Eroilor 29, Brasov, Romania, tiberiu.foris@unitbv.ro, +40 745070806
} 
Agritourism plays a significant role for sustainable development. In this regard it is important to analyse the evolution of the development of the agritourism in Romania, in order to outline and propose new directions of development and strategic approaches, dedicated to this field.

\section{THEORETICAL BACKGROUND}

The current Romanian legislation has defined tourist boarding houses as establishments of tourist reception with an accommodation capacity of up to 15 rooms, having a total of maximum 60 beds, operating in the citizens dwellings or in independent buildings and which provide tourist accommodation and conditions for preparing and serving meals in special set up places (Foris, 2011), and agritourist boarding houses as establishments of tourist reception with an accommodation capacity of up to 8 rooms, in the rural area, operating in the citizens dwellings or in independent buildings and which provide tourist accommodation and conditions for preparing and serving meals in special set up places and the possibility to attend the household's activities.

The exceptional tourism potential of Romania has two main components: the natural component, represented by spectacular landscapes, varied configuration of the relief, favourable climate conditions and lots of natural therapeutic spas, and the historical component, represented by traces of succeeding civilizations that had lived on Romanian territory since ancient times, monuments and lay or religious art objects, museums and museum collections, beautiful and original ethnographical and folklore elements and actual prestigious achievements (Sumovoschi and Moraru, 2015).

Agritourism was initially practiced by peasants who had additional accommodation and since then, this form of tourism is constantly expanding and has also become a direction for action in order to achieve a sustainable development of the countryside. Romania is actually following the successful models developed in Western Europe, where agritourism occupies a leading position in the tourists preferences (National Institute of Statistics, 2017). That is given to the fact that it is among the countries with a real agritourism potential, and it has become more and more visible at the European level in the latest years, especially thanks to the landscapes and the wild nature, to which the modern people now want to return. Romania is a country with a genuine agritourism potential (Ciurea, 2011) with multiple traditions which were preserved along the centuries and which have been integrated by the technological revolution in the Western Europe.

Establishments of tourists reception with functions of tourists accommodation such as tourist boarding houses and agritourist boarding houses can be classified as small enterprises, which have played and still play a vital role in any national economy, representing an important factor of economic growth (Chitu and Tecău, 2012).

\section{MATERIALS AND METHODS}

The analysis was carried out on the basis of the statistical data provided by the National Institute of Statistics published in the Romanian Tourism - Statistical Summary for the period between 2006 and 2016 . Quantitative and comparative analyses were carried out regarding the total number and the existing accommodation capacity for tourist boarding houses and agritourist boarding houses and the numerical evolution for domestic arrivals and international arrivals throughout the period between 2006 and 2016 .

\section{RESULTS AND DISCUSSION}

We started by analysing the numerical evolution for tourist boarding houses and agritourist boarding houses in Romania.

During the analysed period, we find a steady increase for the number of tourist boarding houses and agritourist boarding houses. A decrease can be noticed for agritourist boarding houses in 2011, which can be attributed to the global economic crisis. From 2012, there can be noticed a significant increase for agritourist boarding houses, a situation that may be caused by the implementation of the National Rural Development Program of Romania (PNDR) 2007-2013 and 2014-2020. Among the activities of the program PNDR 2007-2013 was the 'Measure 313 
Proceedings of the 2018 International Scientific Conference 'Economic Sciences for Agribusiness and Rural Economy' No 1, Warsaw, 7-8 June 2018, pp. 81-86

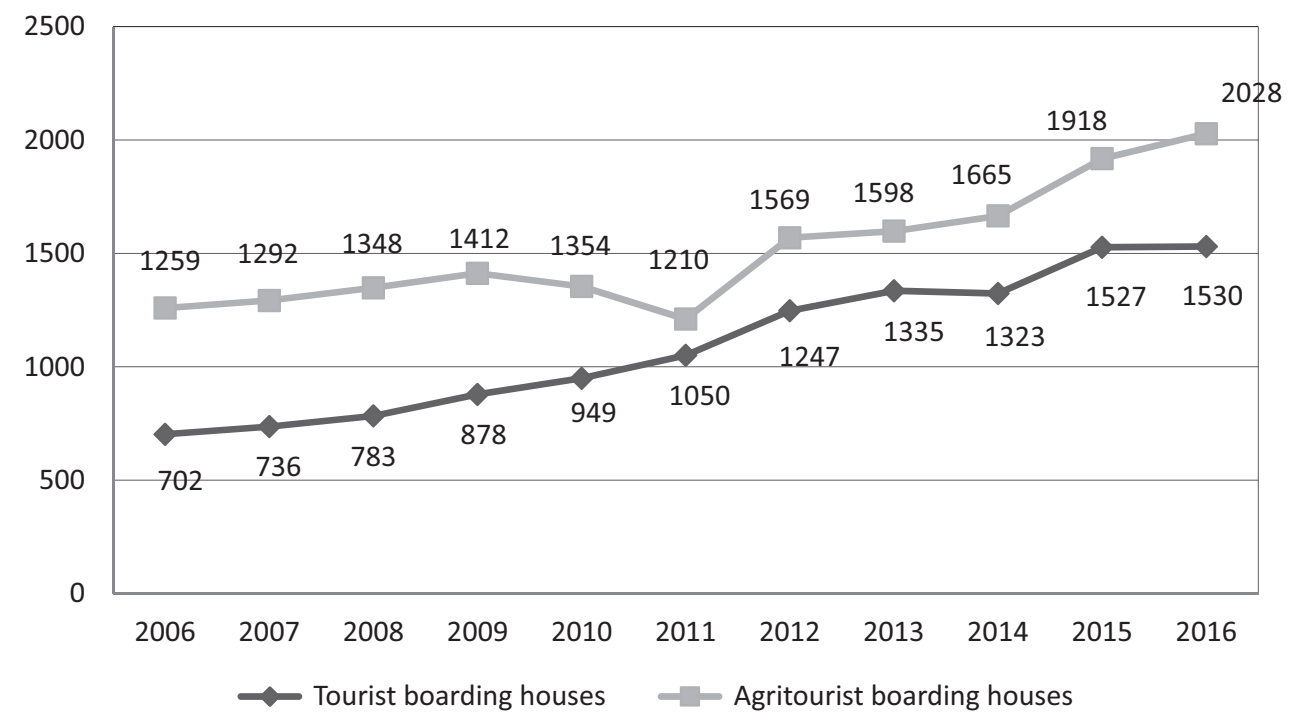

Figure 1. Establishments of tourist reception with functions of tourist accommodation by type of establishments (tourist boarding houses and agritourist boarding houses)

Source: adapted National Statistics Institute (2018).

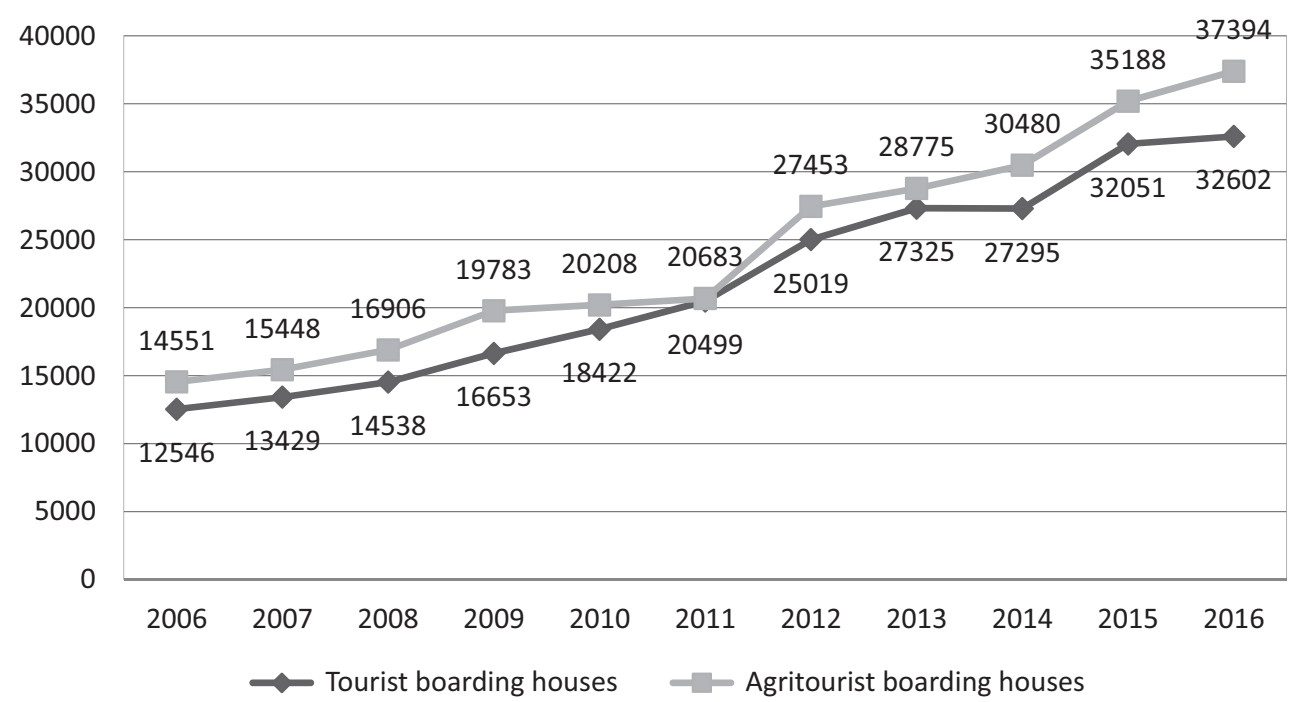

Figure 2. Establishments of tourist reception with functions of tourist accommodation and the tourists' accommodation capacity for tourist boarding houses and agritourist boarding houses

Source: adapted the National Statistics Institute, Tourism of Romania - statistical summary 2006-2017.

- Encouragement of tourism activities', which was framed under Axis III 'Improving the quality of life in rural areas and diversification of the rural economy' (Ministry of Agriculture and Rural Development, 2012).
Analysing the tourists' accommodation capacity for the studied period, we notice a significant increase regarding agritourist boarding houses (156\%) and tourist boarding houses $(159 \%)$. It is also necessary to mention that the increase of the units can be 
based on the fact that in 2014 started the National Rural Development Programme of Romania 2014-2020 (National Rural Development Program, 2017). The sub-measure 6.2 'Support for the establishment of non-agricultural activities in rural areas' included in the Programme, aims to support diversification by setting up and developing micro-enterprises and small businesses in the non-agricultural field in rural areas. The main objective of these activities is to create jobs, to contribute to sustainable economic development and to reduce poverty in rural areas.

In order to determine the sustainability of agritourism in Romania, it is necessary to analyse the demand for this type of activities. For this reason, we will analyse the number of tourist arrivals during the period 2006-2016 in tourist boarding houses and agritourist boarding houses.

Analysing the tourists' arrivals in tourist boarding houses and agritourist boarding houses for the studied period, we notice a significant increase. In the case of the tourists' arrivals, the influence of the economic crisis can be also noticed, leading to a small decrease in arrivals during 2008-2010 both for foreigners and Romanian tourists. After 2011 there have been steady increases in the flow of ar- rivals for both the domestic and the international tourism flows but an slow evolution of the number of international arrivals.

Agritourism plays an important role for sustainable development, but the question is, if agritourism plays an important role in the Romanian tourism industry. In this regard, we will conduct an analysis to determine the contribution (in percent) of the number and accommodation capacity of tourist boarding houses and agritourist boarding houses in the total number and accommodation capacity of accommodation units in Romania.

In Table 1 we represented the numerical evolution of the establishments of tourist reception with functions of accommodation in Romania. We notice that in 2006 the total number of registered units was 4,710, of which 1961 were represented by tourist boarding houses and agritourist boarding houses. In 2016 the total number of units was 6,946 , of which 3,558 were tourist boarding houses and agritourist boarding houses, namely $51.22 \%$ of the total number of units and compared to 2006, their number increased by $9.59 \%$, the results following a positive trend. It is important to keep in mind that in most cases hotels, hostels, bungalows, etc. are located in or near urban

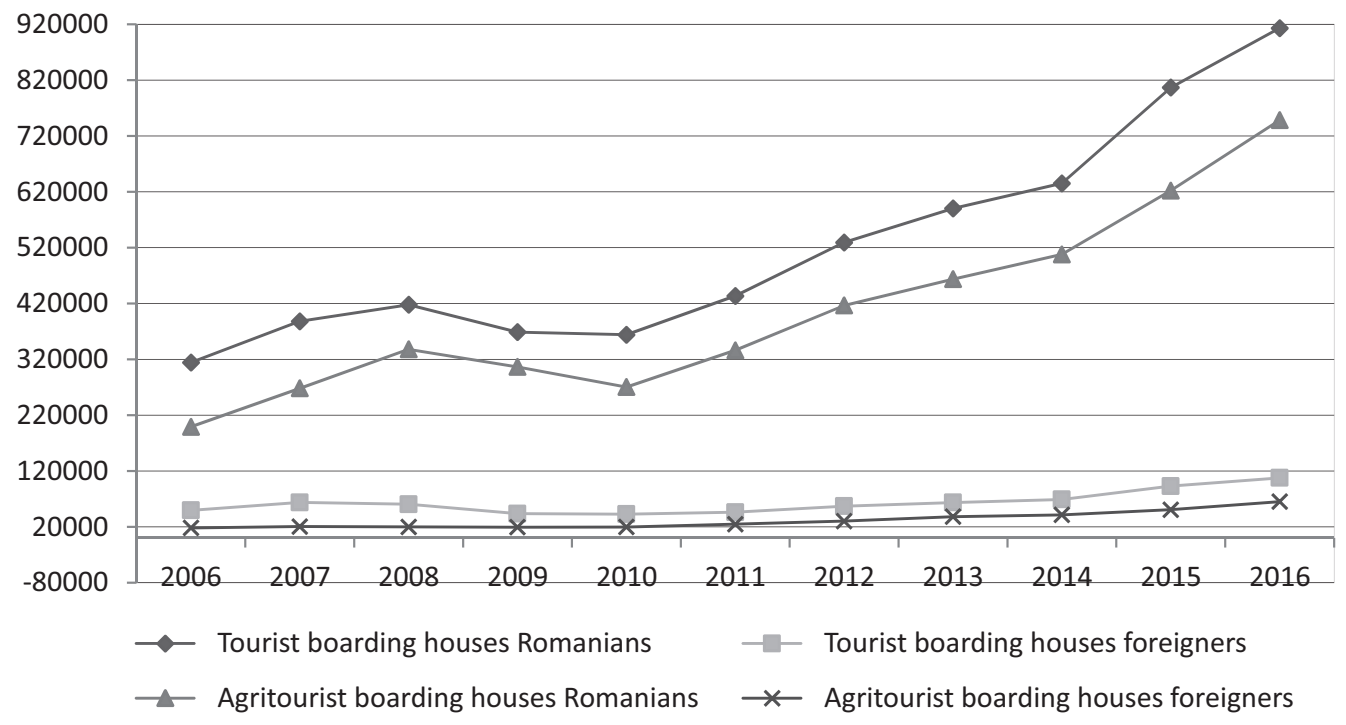

Figure 3. Tourists' arrivals in the establishments of tourists' reception with functions of tourists' accommodation by type of establishments - tourist boarding houses and agritourist boarding houses

Source: adapted National Statistics Institute (2018). 
Table 1. The contribution of the number and accommodation capacity of tourist boarding houses and agritourist boarding houses in the total number and accommodation capacity of accommodation units in Romania

\begin{tabular}{|c|c|c|c|c|c|c|}
\hline Reference & $\begin{array}{c}\text { Number of } \\
\text { establishments } \\
\text { of tourists } \\
\text { reception } \\
\text { with functions } \\
\text { of tourists } \\
\text { accommodation }\end{array}$ & $\begin{array}{c}\text { Number of tourist } \\
\text { boarding houses } \\
\text { and agritourist } \\
\text { boarding houses }\end{array}$ & $\begin{array}{c}\text { Contribution } \\
(\%)\end{array}$ & $\begin{array}{c}\text { Accommodation } \\
\text { capacity } \\
\text { for } \\
\text { establishments } \\
\text { of tourists } \\
\text { reception } \\
\text { with functions } \\
\text { of tourists } \\
\text { accommodation }\end{array}$ & $\begin{array}{c}\text { Accommodation } \\
\text { capacity } \\
\text { for tourist } \\
\text { boarding houses } \\
\text { and agritourist } \\
\text { boarding houses }\end{array}$ & $\begin{array}{c}\text { Contribu- } \\
\text { tion } \\
(\%)\end{array}$ \\
\hline 2006 & 4710 & 1961 & 41.63 & 287158 & 27097 & 9.44 \\
\hline 2007 & 4694 & 2028 & 43.20 & 283701 & 28877 & 10.18 \\
\hline 2008 & 4840 & 2131 & 44.03 & 294210 & 31444 & 10.69 \\
\hline 2009 & 5095 & 2290 & 44.95 & 303486 & 36436 & 12.01 \\
\hline 2010 & 5222 & 2302 & 44.08 & 311698 & 38630 & 12.39 \\
\hline 2011 & 5003 & 2260 & 45.17 & 278503 & 41182 & 14.79 \\
\hline 2012 & 5821 & 2816 & 48.38 & 301109 & 52472 & 17.43 \\
\hline 2013 & 6009 & 2933 & 48.81 & 305707 & 56100 & 18.35 \\
\hline 2014 & 6130 & 2988 & 48.74 & 311288 & 57775 & 18.56 \\
\hline 2015 & 6821 & 3445 & 50.51 & 328313 & 67239 & 20.48 \\
\hline 2016 & 6946 & 3558 & 51.22 & 328888 & 69996 & 21.28 \\
\hline
\end{tabular}

Source: adapted National Statistics Institute (2018).

areas, and at present, rural areas in Romania cover 87.1\% (Management Authority for PNDR, 2013) of the country's territory, so there are perspectives for more favourable development of agritourism.

The values for the total accommodation capacity for existing establishments of tourist reception with functions of accommodation are also highlighted in Table 1. In 2016, 21.28\% of the total accommodation capacity was represented by the tourist boarding houses and agritourist boarding houses and their number has increased by $11.48 \%$ compared to 2006 .

Various development strategies have been developed over time in Romania, which concerned also the agritourism field, such as certain actions provided by the National Tourism Development Master Plan 2007-2026, one of them is Action 35, about encourage and facilitate the formation of the destination of rural areas. There are also actions targeting agritour- ism in the Strategy of Ecotourism Development in Romania (National Institute for Ecotourism Development in Romania, 2009), one of them refers to the simplification of the autorization procedure for rural tourism, but we consider that agritourism requires a dedicated strategy for a steady, sustainable and efficient development.

\section{CONCLUSIONS}

During the period 2006-2016, agritourism has experienced a real development in Romania.

Romania continued the development of agritourism accommodation units, thus increasing the number of both internal and international arrivals. A big share in the development of this tourism sector was constituted by the support provided to entrepreneurs through the development programs, by 
providing non-reimbursable funds for the development of tourism in rural areas.

In this regard, but given the potential existing at the moment, a strategy dedicated to agritourism is more than necessary in Romania. The agritourism development strategy should include several lines of action, covering sustainable development; transport and accommodation infrastructure areas; educating entrepreneurs to deliver high-quality services; educating tourists and guiding them to rural areas by presenting the advantages during tourism fairs or by promoting them on all existing channels, creating a positive international image by establishing links with organizations, travel centres and international travel agencies, in order to facilitate the exchange experience, promoting and encouraging the diversification of cultural activities and traditional events through organizing various thematic events. In this respect, the paper opens up topics for future research.

\section{REFERENCES}

1. Caratus Stanciu, M. (2017). Agrotourism And Rural Tourism The Way Of Sustainable Development In Rural Areas Of Sibiu County - Romania, Oltenia. Studii şi Comunicări. Ştiințele Naturii, 33 (2), p. 1.

2. Chitu, I.B., Tecau, A.S. (2012). Consultancy services in marketing and management - Growth factor of competitiveness for small and medium enterprises. Journal of Applied Economic Sciences, 7, 4 (22), pp. 373-379.

3. Ciurea, I.V. (2011). Strategii de dezvoltare rurală durabilă prin agroturism [Sustainable rural development strategies through agritourism]. TERRA NOSTRA, Iaşi.
4. Dorobantu, M.R., Nistoreanu P. (2012). Rural Tourism and Ecotourism- the Main Priorities in Sustainable Development, Orientations of Rural Local Communities in Romania. Economy Transdisciplinarity Cognition, 15 (1), p. 3.

5. Foris, D. (2011). Reglementarea activităților din turism [Regulation of tourism activities]. Editura LuxLibris.

6. Management Authority for PNDR (2013). Analiza socio-economică în perspectiva dezvoltării rurale 2014 -2020 .

7 Ministry of Agriculture and Rural Development (2012). Ghidul Solicitantului. Încurajarea Activităților Turistice, Măsura 313.

8. Ministry of Agriculture and Rural Development (2017). Programul Național de Dezvoltare Rurală 2014-2020 [National Rural Development Program 2014-2020]. Ghidul Solicitantului - Submăsura 6.2 'Sprijin pentru înființarea de activități neagricole în zone rurale'.

9. Ministry of Economy, Commerce and Tourism (2007). National Tourism Development Master Plan 2007-2026 .

10. National Institute for Ecotourism Development in Romania (2009). Strategy of Ecotourism Development in Romania.

11. National Statistics Institute (2018). Turismul României - breviar statistic 2006-2017 [Tourism of Romania - statistical summary 2006-2017].

12. Nistoreanu, P. (2007). Aprecieri asupra fenomenului turistic rural [An appreciation of the rural tourism phenomenon]. Revista de Turism, 3, p. 17.

13. Sumovoschi, D.C., Moraru, R.A. (2015). Factori motivationali in agroturism [Motivational factors in agritourism]. Turismul rural romaniesc in contextul dezvoltarii durabile. Actualitate si Perspective, 38, p. 133. 